\title{
A Preliminary Study: What Is Love in a Marriage?
}

\author{
Hoesni, S. M. ${ }^{1}$, Hashim, I. H. M. ${ }^{2} \&$ Ab Rahman, Z. ${ }^{3}$ \\ ${ }^{1}$ School of Psychology and Human Development, Faculty of Social Sciences and Humanities, Universiti \\ Kebangsaan Malaysia, Bangi, Malaysia \\ ${ }^{2}$ School of Social Sciences and Humanities, Universiti Sains Malaysia, Penang, Malaysia \\ ${ }^{3}$ Department of Theology and Philosophy, Faculty of Islamic Studies, Universiti Kebangsaan Malaysia, Bangi, \\ Malaysia \\ Correspondence: Hoesni, S. M., School of Psychology and Human Development, Faculty of Social Sciences and \\ Humanities, Universiti Kebangsaan Malaysia, 43600 UKM Bangi, Selangor, Malaysia. Tel: 60-3-8921-3628. \\ E-mail: smh@ukm.my
}

Received: June 4, 2012 Accepted: June 16, $2012 \quad$ Published: July 16, 2012

doi:10.5539/ass.v8n9p57

URL: http://dx.doi.org/10.5539/ass.v8n9p57

\begin{abstract}
This study investigates how urban Malays give meanings to love within marriage. A total of 245 participants attending a compulsory premarital program in Klang Valley, Malaysia agreed to take part in this study. Questionnaires consisting of personal and relationship background were distributed to participants. How participants give meanings to love which exists in a marriage were rated using a self developed prototype list of Subjective Meanings of Marital Love (SMML). Data were analyzed using Statistical Package for Social Sciences version 19 for Windows (SPSS 19) and Sternberg's Triangular Love Theory was applied when examining possible components of love which exists within marriage. Results showed that the most agreeable elements of love within marriage belonged to commitment and intimacy component. On the other hand, the least agreeable elements of love within marriage came from the passion component of love. Overall, the most unique results showed that participants reported that love in a marriage as having strong relationship towards God. Findings implied the importance of investigating love experiences which is specific to context of love experience - such as love within marriage and faith aspects when studying close relationships.
\end{abstract}

Keywords: subjective meanings of love, marital love, prototype, soon-to-be-married, urban Malays

\section{Introduction}

The euphoric feelings of love experienced in early marriage may soon be challenged by responsibilities and commitment within the marriage. To illustrate, the daily routine of juggling between meeting the needs of work and family can easily create stress and conflict between married couples. This condition worsens when newly wedded couples are burdened with new responsibilities such as caring for a newborn in the family. Lack of quality time between the husband and wife may harm existing marital love relationships. This includes the inability to pursue joint quality activities by spouses. Moreover, the euphoric feelings of romantic love experienced as couples will eventually deteriorate and gradually move towards companionate love which revolves around commitment in a marriage (Bonds-Raacke et al., 2001; Ruvolo and Veroff, 1997). The gradual decrease in romantic love that married couples once experienced may be perceived by married individual as an experience of "deterioration of love". This experience can eventually results in unhappy and unsatisfactory marriages. On the other hand, the well-being of a married individual who is not happy and dissatisfied can be badly affected. For example, research found that marital instability and distress can affect one's physical health (Kiecott-Glaser et al., 1993; Roberts et al., 2005). Findings also indicated that marital distress promotes depression among adults (Assh and Byers, 1996; Coyne et al., 1987; Horneffer and Fincham 1996; Ismail, 2004; Jackman-Cram et al., 2006; Low and Stocker, 2005).

The perception of "deterioration of love" within marriage can also influence other people in the family including children. Findings suggest that unhappy marriages cannot create a conducive environment for the development of family members (Crouter et al., 1999; Ismail, 2004; Webster-Stratton, 1990; Yela, 1998). Unhappy and 
depressed parents may not be able to play their parental roles as effectively (Webster-Stratton, 1990). Murray et al. (2006) discovered that parents experiencing depression may not provide appropriate support for their children in even the simplest tasks such as helping their children with homework. A longitudinal study showed that children with parents experiencing marital distress and conflict prevented them from making positive adjustments in adulthood (Cui et al., 2005). Furthermore, the depressed mood and marital conflict between parents were also found to harm children's adjustment (Low and Stocker, 2005). Krishnakumar and colleagues (2003) found that children with parents who practice negative interactions were also prone to poor social skills in dealing with daily life crises.

Moreover, other studies found that marital distress and destructive marital conflict contribute to other problems that are related to the dysfunctional and psychopathological behavior of the married couples and children (Coie et al., 1993; Olsofsky, 1995). Children of parents who experienced marital distress were more likely to suffer from internalizing problems such as anxiety and depression (Low and Stocker, 2005), prone to juvenile delinquency (Patterson and Dishion, 1985) and conduct disorders (Fincham and Bradburry, 1990; Webster-Stratton, 1990). In addition, conduct disorder is described as "a pervasive adolescent disorder with clinically significant antisocial behaviors such as excessive non-compliance, aggression, stealing, lying, truancy, violence, destructiveness, cruelty, and sexually coercive behavior" (American Psychiatric Association, 1994, p.85). Unfortunately, it remains as one of the most difficult syndromes to treat clinically (Kieley, 2002). Studies have discovered that many children that display conduct disorder are with parents who experience marital distress. Distressed parents were prone to show irritable, critical and punitive parenting skills towards their children, harsh or inconsistent disciplining and low monitoring (Frick, 1994; Gottman and Katz, 1989; Webster-Stratton, 1990).

"Deterioration of love" may also eventually lead to divorce. Studies carried out by Asmah (1979), Jones (1980, 1981, 1997) and Kling (1995) showed that divorce rates among Malays are increasing gradually albeit not significantly. The effects of divorce are harmful to the individuals within the broken marriage and also the children within the broken family. For instance, a longitudinal study carried out by Yu et al. (2010) found that there were associations between divorce and poor quality parent-adult child relationships. Moreover, Lizardi et al. (2010) found that female children who lived with a stepparent were more prone to attempt suicide compared to males.

The above discussion highlights problems that can be associated with 'lack' of love within marriage. In this regard, love within marital relationship should be seen as a positive aspect that can help strengthen the marriage and minimize the risk of unhappy marriages and divorce. As such, it is important to understand love as viewed within marriages.

\section{Method}

\subsection{Sampling and Procedure}

Participants in this study were 245 (114 male, 131 female) soon-to-be-married urban Malays. Participants were those who attended a compulsory premarital course at six randomly selected centers around Kuala Lumpur using simple random or tombola method as suggested by Dyer (2006). The centers were then contacted to gain permission and distribute questionnaires. All completed questionnaires were collected and returned to researchers for analysis.

\subsection{Measurements}

Questionnaires in this study were divided into three sections. The first section consisted of questions regarding background information of participants (gender, age, marital status, education level, occupation and personal monthly income). The second section consisted of questions relating to participants' relationship status (whether the participant has a particular partner to marry, how the partner was chosen, the length of time they were in the relationship, how they first met, reasons to marry, whether a marriage date was set, time left before their wedding day, and whether participants were in love at that time with their partner). The third section contained questions regarding participants' views on marital love. A prototype list of marital love was developed. The concept of marital love was labeled as Subjective Meanings of Marital Love (SMML) which is a type of measurement used to explore urban Malay individuals' view on marital love with 40 items. The original idea of developing SMML was adapted from Fehr (1988). The scale was developed from free listing of subjective meanings of marital love in a study by Hoesni et al. (2012). This researcher adapted the keyword extraction process as recommended by Braun and Clarke (2006). The open-ended answers with similar keywords or 
phrases were coded, thus, resulting in different themes and a total of 40 items. Participants were asked to rate each of the 40 items which consists of subjective meanings of marital love. The items were rated by participants using the 5 point-Likert scale $(1=$ almost never or never true to $5=$ totally true). The highest score for SMML was 200 and the lowest score was 40 .

\subsection{Analysis}

Statistical Package for Social Sciences version 19 for Windows (SPSS 19) was applied to manage and assist the researcher in analyzing the collected data. Data were analyzed using descriptive and inferential statistics. Descriptive statistics were carried out to analyze the descriptive background of participants involved using minimum, maximum, percentages, mean and standard deviation scores. Subjective Meanings of Marital Love (SMML) containing 40 items were subjected to principal component analysis (PCA). The PCA was applied to summarize the items according to Triangular Love Theory (Sternberg, 1986) which comprised of three components of love - intimacy, passion and commitment. Data reduction process such as PCA was compulsory in the process of developing a measurement in a study (Hair et al., 2006; Loewenthal, 2001; Tabachnick and Fidell, 2007). Data in this study went through several procedures to investigate the suitability for PCA specifically, correlation matrix, Kaiser-Meyer-Olkin (Kaiser, 1970, 1974) and the Bartlett's Test of Sphericity (Bartlett, 1954). The data were subjected to PCA only after it achieved the minimum requirement for PCA. If the data were found to be suitable, Varimax and Oblimin Rotation were used to investigate the structure within SMML using Triangular Love Theory (Sternberg, 1986) as a guideline. Before proceeding to PCA, the suitability of factor analysis was assessed through several procedures as follows. First, this was carried out by inspecting the correlation matrix for the items and results showed the presence of many correlation matrices with values of 0.30 and above. The Kaiser-Meyer-Olkin value was 0.915 exceeding the recommended value at 0.60 (Kaiser, 1970, 1974) and the Bartlett's Test of Sphericity (Bartlett, 1954) reached statistical significance which supports the factorability of the correlation matrix. Thus, PCA was executed.

\section{Results and Discussion}

\subsection{Personal and Relationship Background of Respondents}

Participants in this study were 131 females (53.5\%) and 114 males (46.5\%) with mean age of 25.4 years. The age ranged from 17 until 47 years old. Most of the participants consisted of singles (97.1\%). The rest (2.8\%) were divorced or widowed. All participants were Malays and Muslims. The highest academic or educational qualifications of participants were Malaysian Certificate of Education (SPM) (61.0\%), followed by Diploma (12.2\%) and Malaysian Lower Certificate of Education (LCE/SRP/PMR) (10.7\%). Majority of participants were employed (91.0\%) and working under service sector (33.1\%), followed by manufacturing factory $(22.3 \%)$ and business sector (19.1\%). The mean of reported monthly income was RM1273.88.

Participants also reported reasons on decisions to marry. There was a $91.6 \%$ response rate. A total of 229 of the 245 participants responded to the questions. For this question, they reported more than one reason to be married. Results showed the highest reasons for participants to marry were to abide to religious law (74.7\%), followed by own wish (66.4\%) and to be loved (61.6\%). The least reason for participants to marry was due to friend's pressure (4\%). More than half $(59.8 \%)$ of the participants decided on their wedding date and the mean of months left before participants' wedding day was 5.3 months.

\subsection{Subjective Meanings of Marital Love (SMML)}

Results showed that the ten most agreeable items that participants agreed with were "requires Allah's blessings" $(\mathrm{M}=4.78, \mathrm{SD}=0.50)$, "existence of affection" $(\mathrm{M}=4.66, \mathrm{SD}=0.50)$, "mutual need" $(\mathrm{M}=4.63, \mathrm{SD}=0.58)$, "mutual yearning" $(\mathrm{M}=4.63, \mathrm{SD}=0.55)$, "existence of thoughtfulness" $(\mathrm{M}=4.62, \mathrm{SD}=0.51)$, "existence of responsibility" ( $\mathrm{M}=4.62, \mathrm{SD}=0.55)$, "mutual respect" $(\mathrm{M}=4.62, \mathrm{SD}=0.56)$, "existence of warmth" $(\mathrm{M}=4.60$, $\mathrm{SD}=0.59)$, "together through thick and thin" $(\mathrm{M}=4.59, \mathrm{SD}=0.61)$ and "existence of sincerity" $(\mathrm{M}=4.58, \mathrm{SD}$ $=0.54$ ).

Conversely, the items that participants least agree regarding the definition of marital love were as follow in ascending order "existence of fantasy" $(\mathrm{M}=3.76, \mathrm{SD}=0.97)$, "existence of extraordinary feelings" $(\mathrm{M}=3.89$, $\mathrm{SD}=0.97)$, "existence of emotional attraction" $(\mathrm{M}=3.91, \mathrm{SD}=1.00)$, "mutual adoration" $(\mathrm{M}=3.99, \mathrm{SD}=$ $0.90)$, "existence of general intercourse" $(\mathrm{M}=4.06, \mathrm{SD}=1.09)$, "existence of physical pleasure" $(\mathrm{M}=4.10, \mathrm{SD}$ $=0.82)$, "existence of physical attraction" $(\mathrm{M}=4.16, \mathrm{SD}=0.81)$, "existence of certainty" $(\mathrm{M}=4.26, \mathrm{SD}=0.71)$, "constantly thinking of spouse" $(\mathrm{M}=4.29, \mathrm{SD}=0.75)$ and existence of comfort" $(\mathrm{M}=4.30, \mathrm{SD}=0.68)$. 
The Principal Component Analysis (PCA) to summarize SMML items were performed to explore components of marital love adapted from Aron and Westbay (1996). This procedure enabled the researcher to summarize items in SMML into components of marital love and make comparisons with existing views of love within the field of psychology.

A total of 40 items were subjected to Principal Component Analysis (PCA). The results of PCA (Table 1) showed the existence of nine components with eigen values exceeding 1 in a respective order of explaining $37.36 \%, 6.77 \%, 5.29 \%, 3.65 \%, 3.39 \%, 3.03 \%, 3.01 \%$ and 2.91 and $2.63 \%$. In addition, an inspection of the scree plot showed a clear break after the third component. By using Cattell's (1966) scree test, it was decided to retain three components for further inspection.

Varimax rotation was executed to assist in interpreting components of subjective meanings of marital love formed by PCA. The rotated solution showed the presence of simple structure (Thurstone, 1947). Both of the components showed a number of strong loadings and all variables loaded strongly on one component. The three components solution explained a total of $49.14 \%$ of the variance with component one contributing $19.85 \%$, component two contributing $15.32 \%$ and component three contributing $13.97 \%$.

In addition, Oblimin rotation was carried out to ensure all items in SMML were summarized under marital love components. The importance of running Varimax and Oblimin rotation assisted the researcher to interpret the components formed from SMML and also decide on which items to be retained or removed (Pallant, 2007). The rotated solution showed the presence of simple structure (Thurstone, 1947). Results in Table 1 showed that all items from SMML fell into three components which were intimacy (11 items), passion (14 items) and commitment (15 items) (Please refer to table A1 and A2 for the overall variable loadings). All the items under the three components were scrutinized with the guidance of Triangular Love Theory (Sternberg, 1986). As a result, the three components resembled general descriptions as described by Triangular Love Theory (Sternberg, 1986) which were intimacy, passion and commitment. Table 1 presents examples of SMML under the three components as produced by PCA. (refer Table 1).

Table 1. Examples of items in SMML 1

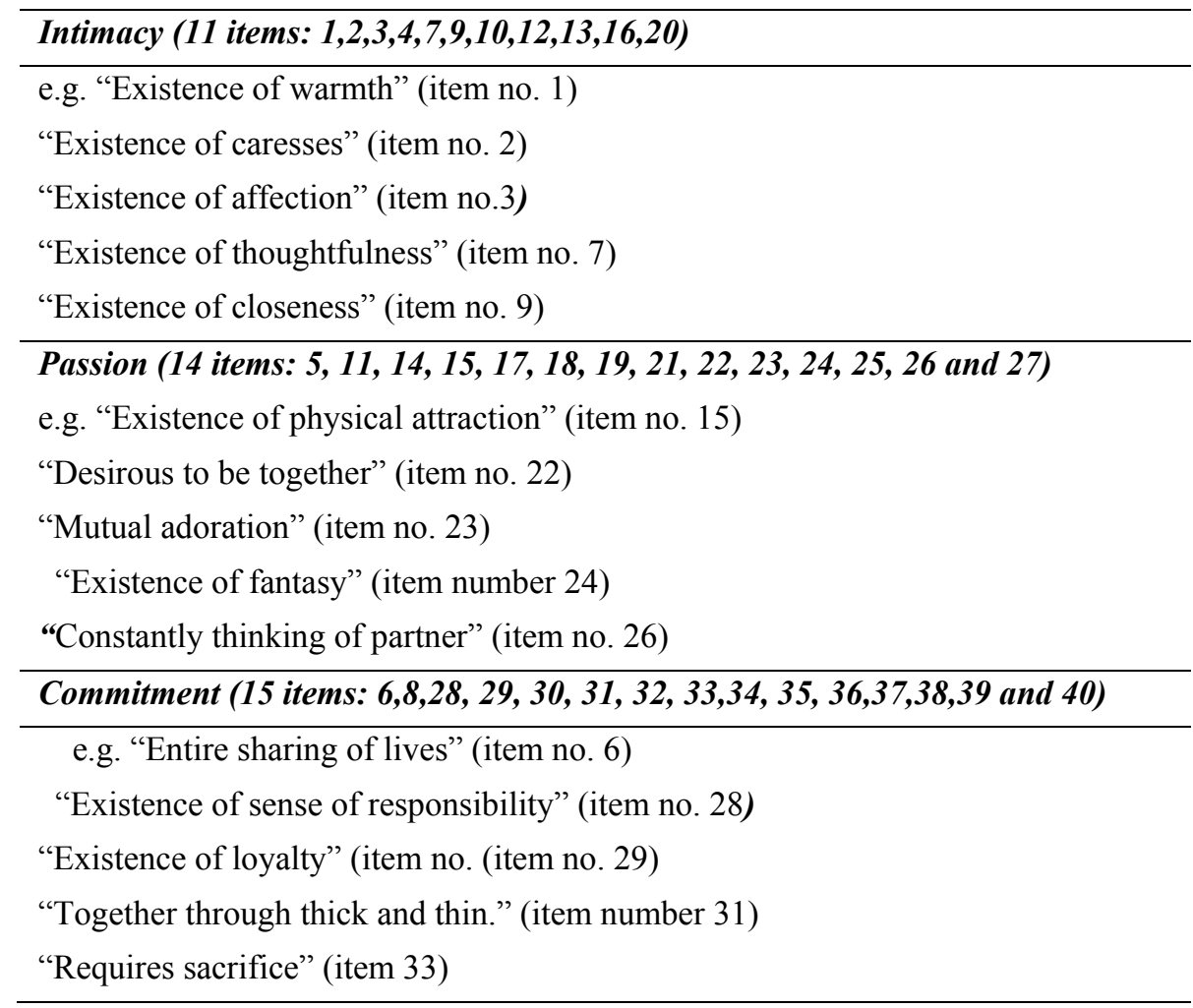

As a result of the items that fell under the three components, the researcher named and defined the three components as Intimacy, Passion and Commitment. The definitions for each component were developed according to the summary of items under each component as describe by Tabachnick and Fidell (2007). Thus, the researcher named and defined the three components as shown in Table 2. (see Table 2). 
Table 2. Definition of SMML 1 according to dimensions

\begin{tabular}{ll}
\hline Intimacy & $\begin{array}{l}\text { The perception that marital love as having qualities that resembles the uniqueness of emotional } \\
\text { closeness between husband and wife. (e.g. - existence of warmth, existence of caresses, } \\
\text { existence of affection, existence of thoughtfulness, existence of understanding). }\end{array}$ \\
Romantic & $\begin{array}{l}\text { The obsession of individual towards spouse. This includes preoccupation and existence of } \\
\text { emotional, spiritual and physical pleasure from spouse. (e.g. - existence of physical attraction, } \\
\text { existence of physical pleasure, desirous to be together, existence of fantasy, constantly thinking } \\
\text { of partner) }\end{array}$ \\
Commitment & $\begin{array}{l}\text { Viewed as a prolonged relationship tied under the influence of culture. This includes Islamic } \\
\text { and Malay marriage maintenance values that were taught through socialization. (e.g. - together } \\
\text { through thick and thin, requires sacrifice, mutual respect, requires patience, and requires Allah's } \\
\text { blessings) }\end{array}$
\end{tabular}

Subjective Meanings of Marital Love (SMML) went through reliability check. A total of 40 items from SMML and components of marital love as suggested by PCA during validity check were tested on their reliability. SMML were found to exceed the minimum requirement of alpha Cronbach as suggested by Anastasi (1988). The summary of reliability test using alpha Cronbach on SMML is shown in Table 3. (see Table 3).

Table 3. Reliability for SMML (40 Items)

\begin{tabular}{cc}
\hline SMML & Reliability $(\alpha)$ \\
\hline Overall SMML (40 items) & 0.96 \\
Intimacy (11 items) & 0.89 \\
Passion (14 items) & 0.89 \\
Commitment (15 items) & 0.93 \\
\hline
\end{tabular}

Findings indicated that the most agreeable items came from the component of commitment and intimacy of subjective meanings of marital love. However, majority of the least favorable items was from passion component of subjective meanings of marital love. Analysis of the most and least agreeable items relating to the meanings of marital love showed that commitment and intimacy aspects of love were seen as more important than passion when characterizing love within marriage.

Findings from this study showed that marital love was frequently coined with elements coming from commitment and intimacy component of marital love. Some of the elements from commitment were gaining the blessings from God, staying together with spouse through thick and thin, and having mutual need and responsibility. Some of the most important elements coming from intimacy component of marital love were existence of warmth, affection, understanding, mutual respect, mutual yearning, thoughtfulness and mutual compromise.

Above all the elements reported by participants, marital love was also seen as something spiritual and sacred. This remained one of the unique and important elements found in this study. This was shown when participants reported marital love requiring "blessings from Allah". Moreover, Islam values their believers to achieve a higher aspect of love which comes from God by lawful marital ties. In fact, to show how important it was to the participants, it appeared in both quantitative and open-ended answers feedback from participants. This implies how urban Malay participants valued marital love by integrating it in order to gain Allah's blessings.

However, the least important elements when participants reported giving meanings towards marital love came from the passion component. Elements were related to earlier stage of relationship such as dating relationship or falling in love relationship. This included fantasy, extraordinary feelings, emotional attraction, mutual adoration, existence of sexual relations, existence of physical pleasure, existence of physical attraction, constantly thinking of spouse.

Hence, marital love as reported from participants was given a specific meaning different from the usual prototype or concept of love that we generally relate to love. Marital love in this study was found to have elements within a stable marital relationship which was lawful by faith and cultural values. This can be seen when marital love was perceived as having qualities which were characterized by maintaining the relationship in a marriage which was blessed by God. In addition, the heart or spirit of marital love flourished through having intimate qualities as instilled by culture which is governed by faith and urban Malay socialization.

This coincides with previous findings carried out by Desai et al. (1990) which supported the importance of God when relating to love. Specifically, Desai et al. (1990) conducted a study investigating how American and Malay undergraduates perceived love in which they found different patterns on how American and Malay undergraduates perceived love. Furthermore, they found that Malay undergraduates related love to God and 
perceived romantic love out of wedlock as something that lures humans from remembering God. Findings by Desai et al. (1990) also indicated that Malays perceived romantic love as hazardous and have less autonomy when perceiving marital love. Although their study did not specifically focus on marital love, love was nevertheless perceived as something sacred and related to God. Findings in this study also suggested urban Malays perceived establishing blessings and connection of oneself towards God as the ultimate goal in life. This was directly related to Islamic philosophy on submission to God. This included guidelines and teachings in Islam from the Koran and Hadith which are the collection of sayings and behavior of Prophet Muhammad in order to gain blessings from God.

\section{Conclusion}

In summary, this study suggests that how a person gives meanings towards love within marriage have some relationship to their social learning and life experiences. Participants perceived gaining blessings from God as most important compared to the individual they loved. "The need for blessings from Allah" was reported to be most important, abstract and unique element reported by participants in this study when viewing marital love. Future studies on love should consider cultural aspects specifically religious affiliation to enrich scientific understanding on close relationships within psychology field.

\section{References}

American Psychiatric Association. (1994). Diagnostic and statistical manual of mental disorders: DSM-IV. (4th ed.). Washington (DC): American Psychiatric Association

Anastasi, A. (1988). Psychological testing. (6 ${ }^{\text {th }}$ ed.). New York: Macmillan.

Aron, A., \& Westbay, L. (1996). Dimensions of the prototype of love. Journal of Personality and Social Psychology, 70(3), 535-551. http://dx.doi.org/10.1037/0022-3514.70.3.535

Asmah, A. (1979). Pola perkahwinan pertama orang Melayu di Kuala Lumpur dan Petaling Jaya, tahun 1970an: Satu analisis awal. Ilmu Alam, 8, 1-7.

Assh, S. D., \& Byers, S. E. (1996). Understanding the co-occurrence of marital distress and depression in women. Journal of Social and Personal Relationships, 13(4), 537-552. http://dx.doi.org/10.1177/0265407596134004

Bartlett, M. S. (1954). A note on the multiplying factors for various chi square approximations. Journal of the Royal Statistical Society, 16(Series B), 296-298.

Bonds-Raacke, J. M., Bearden, E. S., Carriere, N. J., Anderson, E. M., \& Nicks, S. D. (2001). Engaging distortions: Are we idealizing marriage? The Journal of Psychology, 135(2), 179-184. http://dx.doi.org/10.1080/00223980109603689

Braun, V., \& Clarke, V. (2006). Using thematic analysis in psychology. Qualitative Research in Psychology, 33(2), 77-101. http://dx.doi.org/10.1191/1478088706qp063oa

Cattell, R. B. (1966). The scree test for number of factors. Multivariate Behavioral Research, 1(2), $245-276$. http://dx.doi.org/10.1207/s15327906mbr0102_10

Coie, J. D., Watt, N. F., West, S. G., Hawkins, J. D., Asarnow, J. R., Markman, H. J., ... \& Long, B. (1993). The science of prevention: A conceptual framework and some directions for a national research program. American Psychologist, 48(1),1013-1022. http://dx.doi.org/10.1037/0003-066X

Coyne, J. C., Kahn, J., \& Gotlieb, I. H. (1987). Depression, family interaction and psychopathology: Theories, methods, and findings. New York: Plenum Press.

Crouter, A. C., McHale, S. M., \& Tucker, C. J. (1999). Does stress exacerbate parental differential treatment of siblings? A pattern-analytic approach. Journal of Family Psychology, 13(2), $286-299$. http://dx.doi.org/10.1037/0893-3200.13.2.286

Cui, M., Conger, D., \& Lorenz, F. O. (2005). Predicting change in adolescent adjustment from change in marital problems. Developmental Psychology, 41(5), 812-823. http://dx.doi.org/10.1037/0012-1649.41.5.812

Desai, S. R., McCormick, N. B., \& Gaeddert, W. P. (1990). Malay and American undergraduates' beliefs about love. Journal of Psychology \& Human Sexuality, 2(2), 93-116. http://dx.doi.org/10.1300/J056v02n02_07

Dyer, C. (2006). Research in psychology: A practical guide to methods and statistics. Victoria: Blackwell Publishing.

Fehr, B. (1988). Prototype analysis of the concepts of love and commitment. Journal of Personality and Social Psychology, 55, 557-579. http://dx.doi.org/10.1037/0022-3514.55.4.557

Fincham, D., \& Bradbury, T. N. (1990). The psychology of marriage: Basic issues and applications. New York: Guilford Press. 
Frick, P. J. (1994). Family dysfunction and the disruptive behavior disorders: A review of recent empirical findings. In T.H.E. Ollendick \& R.J. Prinz (Eds.), Advances in clinical child psychology (Vol. 16, pp. 203-226). New York: Plenum.

Gottman, J. M., \& Katz, L. F. (1989). Effects of marital discord on young children's peer interaction and health. Developmental Psychology, 25(3), 373-381. http://dx.doi.org/10.1037/0012-1649.25.3.373

Hair, J. F., Black, B., Babin, R., Anderson, \& Tatham, R. (2006). Multivariate data analysis. (6th ed.). Upper Saddle River, NJ: Prentice Hall.

Hoesni, S. M., Mohd Suhaimi Mohamad, Sarah Waheeda Mohd Hafidz, Sheau Tsuey Chong, \& Nasrudin Subhi. (2012). Meneroka konsep cinta dalam perkahwinan dalam kalangan melayu bandar yang akan berkahwin. (Exploring Love Concepts within Marriage among Soon-To-Be-Married Urban Malays) eBangi Journal of Social Sciences and Humanities, 7(1), 76-83.

Horneffer, K. J., \& Fincham, D. (1996). Attributional models of depression and marital distress. Personality and Social Psychology Bulletin, 22(7), 678-689. http://dx.doi.org/10.1177/0146167296227003

Ismail, R. (2004). Hubungan kesulitan ekonomi dengan kefungsian keluarga, hubungan perkahwinan dan tingkah laku keibubapaan etnik Rungus, Iranun dan Melayu. Kota Kinabalu: Universiti Malaysia Sabah.

Jackman-Cram, S., Dobson, K. S., \& Martin, R. (2006). Marital problem-solving behavior in depression and marital distress. Journal of Abnormal Psychology, 115(2), 380-384. http://dx.doi.org/10.1037/0021-843X.115.2.380.

Jones, G. W. (1980). Trends in marriage and divorce in Peninsular Malaysia. Population Studies, 34(2), $279-292$. http://dx.doi.org/10.1080/00324728.1980.10410390

Jones, G. W. (1981). Malay marriage and divorce in Peninsular Malaysia: Three decades of change. Population and Development Review, 7(2), 255-278. http://dx.doi.org/10.2307/1972623

Jones, G. W. (1997). Modernization and divorce: Contrasting trends in Islamic Southeast Asia and the West. Population and Development Review, 23(1), 95-114. http://dx.doi.org/10.2307/2137462

Kaiser, H. (1970). A second generation Little Jiffy. Psychometrika, 35, 401-415. http://dx.doi.org/10.1007/BF02291817

Kaiser, H. (1974). An index of factorial simplicity. Psychometrika, 39, 31-36. http://dx.doi.org/10.1007/BF02291575

Kiecolt-Glaser, J. K., Malarkey, W. B., Chee, M., Newton, T., Cacioppo, J. T. Mao, H. Y., \& Glaser, R. (1993). Negative behavior during marital conflict is associated with immunological down-regulation. Psychosomatic Medicine, 55(5), 395-409.

Kieley, M. K. (2002). Attachment and affect regulation. Family Process, 41(3), $477-493$. http://dx.doi.org/10.1111/j.1545-5300.2002.41312.x

Kling, Z. (1995). The Malay family: Beliefs and realities. Journal of Comparative Family Studies, 26(1), 43-65.

Krishnakumar, A., Buehler, C., \& Barber, B. (2003). Youth perceptions of inter-parental conflict, ineffective parenting, and youth problem behaviors in European-American and African-American families. Journal of Social and Personal Relationships, 20(2), 239-260. http://dx.doi.org/10.1177/02654075030202007

Lizardi, D. M., Thompson, R. G., Keyes, K. M., \& Hasin, D. S. (2010). The effect of parental remarriage following parental divorce on offspring suicide attempt. Families in Society, 91(2), $186-192$. http://dx.doi.org/10.1606/1044-3894.3982

Loewenthal, K. M. (2001). An introduction to psychological tests and scales. (2nd ed.) Philadelphia: Psychology Press Ltd.

Low, S. M., \& Stocker, C. (2005). Family functioning and children's adjustment: Associations among parents' depressed mood, marital hostility, parent-child hostility, and children's adjustment. Journal of Family Psychology, 19(3), 394-403. http://dx.doi.org/10.1037/a0027944

Murray, L., Woolgar, M., Martins, C., Christaki, A., Hipwell, A., \& Cooper, P. (2006). Conversations around homework: Links to parental mental health, family characteristics and child psychological functioning. British Journal of Developmental Psychology, 24(1), 125-149. http://dx.doi.org/10.1348/026151005x83568

Olsofsky, J. D. (1995). Children who witness domestic violence: The invisible victims. Social Policy Report, $9(3), 1-16$.

Pallant, J. (2007). SPSS survival manual: A step by step guide to data analysis using SPSS for Windows (Version 15). England: Open University Press. 
Patterson, G. R., \& Dishion, T. J. (1985). Contributions of families and peers to delinquency. Criminology, 23(1), 63-79. http://dx.doi.org/10.1111/j.1745-9125.1985.tb00326.x

Roberts, B. W., Walton, K. E., \& Bogg, T. R. (2005). Conscientiousness and health across the life course. Review of General Psychology, 9(S), 156-168. http://dx.doi.org/10.1037/1089-2680.9.2.156

Ruvolo, A. P., \& Veroff, J. (1997). For better or for worse: Real-ideal discrepancies and the marital well-being of newlyweds. Journal of Social and Personal Relationships, 14(2), 223-242. http://dx.doi.org/10.1177/0265407597142005

Sternberg, R. J. (1986) A triangular theory of love. Psychological Review, 93, 119-135. http://dx.doi.org/10.1037/0033-295X.93.2.119

Tabachnick, B. G., \& Fidell, L. S. (2007). Using multivariate statistics (5 $5^{\text {th }}$ ed.). Boston: Allyn and Bacon.

Thurstone, L. L. (1947). Multiple factor analysis. Chicago: University of Chicago Press.

Webster-Stratton, C. (1990). Stress: A potential disruptor of parent perceptions and family interactions. Journal of Clinical Child Psychology, 19(4), 302-313. http://dx.doi.org/10.1207/s15374424jccp1904_2

Yela, C. (1998). Temporal course of the basic components of love throughout relationships. Psychology in Spain, 2(1), 76-86.

Yu, T., Pettit, G. S., Lansford, J. E., Dodge, K. A., \& Bates, J. E. (2010). The interactive effects of marital conflict and divorce on parent-adult children's relationships. Journal of Marriage \& Family, 72(2), 282-292. http://dx.doi.org/10.1111/j.1741-3737.2010.00699.x

\section{APPENDIX}

Table A1. Pattern/structure for coefficients: Varimax rotation of three factor solution for SMML 140 items

\begin{tabular}{llll}
\hline Item (no.) & C1 & C2 & C3 \\
\hline Existence of sincerity (38) & .806 & .220 & .112 \\
Mutual communication (37) & .777 & .292 & .064 \\
Mutual respect (34) & .731 & .158 & .361 \\
Require patience (35) & .705 & .263 & .236 \\
Together through thick and thin (31) & .685 & .136 & .151 \\
Existence of loyalty (29) & .678 & .232 & .221 \\
Entire acceptance of partner (36) & .666 & .040 & .223 \\
Existence of fidelity (30) & .665 & .308 & .145 \\
Existence of harmony (39) & .653 & .258 & .177 \\
Requires sacrifice (33) & .583 & .243 & .279 \\
Existence of sense of responsibility (28) & .576 & .156 & .532 \\
Existence of certainty (32) & .561 & .436 & .066 \\
Requires Allah's blessings (40) & .521 & .080 & .424 \\
Existence of friendship (8) & .389 & .255 & .236 \\
Existence of physical pleasure (21) & .155 & .674 & .236 \\
Existence of fantasy (24) & .061 & .655 & .121 \\
Feelings of delights (18) & .239 & .653 & .213 \\
Mutual adoration (23) & .039 & .620 & .221 \\
Existence of sexual relations (19) & .134 & .601 & .001 \\
Existence of physical attraction (15) & .316 & .582 & .222 \\
Constantly thinking of partner (26) & .303 & .582 & .005 \\
Fascination with partner (14) & .262 & .569 & .128 \\
Existence of extraordinary feelings (27) & .291 & .569 & .016 \\
Existence of spiritual pleasure (11) & .235 & .537 & .223 \\
Existence of beauty (17) & .165 & .523 & .476 \\
Existence of emotional attraction (5) & .098 & .521 & .383 \\
Desirous to be together (22) & .114 & .483 & .283 \\
Partner is important (25) & .308 & .462 & .279 \\
Existence of closeness (9) & .392 & .400 & .233 \\
Existence of understanding (19) & .319 & .330 & .299 \\
Existence of affection (3) & .242 & .087 & .751 \\
\hline
\end{tabular}




\begin{tabular}{llll}
\hline Mutual yearning (16) & .275 & .162 & .744 \\
Mutual need (12) & .428 & .048 & .652 \\
Existence of thoughtfulness (7) & .380 & .207 & .634 \\
Mutual attention giving (13) & .331 & .255 & .615 \\
Existence of warmth (1) & -.036 & .223 & .574 \\
Romantic (20) & .140 & .364 & .500 \\
Existence of comfort (4) & .182 & .410 & .490 \\
Entire haring of lives (6) & .485 & .183 & .487 \\
Existence of caresses (3) & .248 & .388 & .408 \\
\hline
\end{tabular}

Table A2. Pattern/structure for coefficients: Oblimin rotation of three factor solution for SMML 140 items

\begin{tabular}{llll}
\hline Item & $\mathrm{C} 1$ & $\mathrm{C} 2$ & $\mathrm{C} 3$ \\
\hline Existence of sincerity & .860 & .039 & -.101 \\
Mutual communication & .816 & .133 & -.160 \\
Mutual respect & .753 & -.041 & .196 \\
Together through thick and thin & .735 & -.032 & -.015 \\
Entire acceptance of spouse & .726 & -.143 & .085 \\
Requires patience & .716 & .098 & .047 \\
Existence of loyalty & .695 & .071 & .043 \\
Existence of fidelity & .672 & .170 & -.051 \\
Existence of harmony & .666 & .111 & -.004 \\
Requires sacrifice & .575 & .101 & .124 \\
Existence of a sense of responsibility & .551 & -.024 & .415 \\
Existence of certainty & .534 & .349 & -.139 \\
Requires Allah's blessings & .522 & -.086 & .326 \\
Entire sharing of lives & .448 & .034 & .382 \\
Existence of friendship & .355 & .167 & .118 \\
Existence of fantasy &. .100 & .714 & -.011 \\
Existence of physical pleasure & -.012 & .700 & .088 \\
Mutual adoration & -.130 & .669 & .108 \\
Feelings of delight & .092 & .658 & .048 \\
Existence of sexual relations & .014 & .649 & -.147 \\
Constantly thinking of spouse & .212 & .585 & -.176 \\
Existence of extraordinary feelings & 200 & .572 & -.159 \\
Fascination with spouse & .151 & .567 & -.031 \\
Existence of physical attraction & .196 & .558 & .055 \\
Emergence of spiritual pleasure & .114 & .526 & .083 \\
Existence of emotional attraction & -.062 & .524 & .289 \\
Existence of beauty & .001 & .499 & .373 \\
Desirous to be together & -.021 & .488 & .185 \\
Partner is important & .208 & .416 & .141 \\
Existence of caresses & .138 & .334 & .309 \\
Existence of closeness & .325 & .331 & .086 \\
Existence of understanding & .248 & .262 & .187 \\
Existence of affection & .153 & -.045 & .739 \\
Mutual yearning & .175 & .032 & .710 \\
Mutual need & .390 & -.124 & .598 \\
Existence of warmth & -.173 & .197 & .582 \\
Existence of thoughtfulness & .301 & .070 & .559 \\
Mutual attention-giving & .235 & .139 & .540 \\
Romantic & .006 & .323 & .436 \\
Existence of comfort & .045 & .365 & .408 \\
\hline
\end{tabular}

